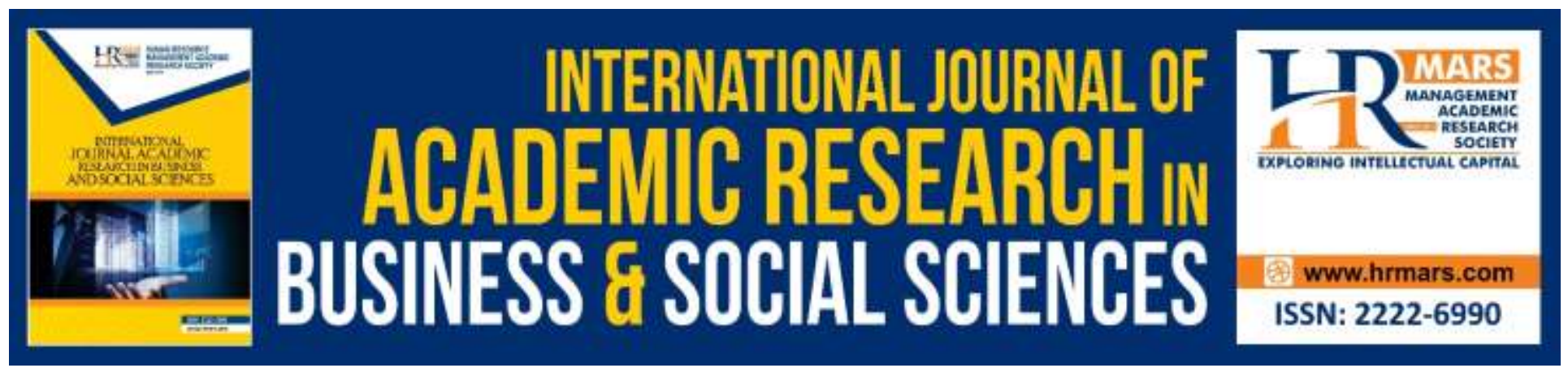

\title{
Factors Influencing Sustainability of Rural Water Supplies Management in Kenya: A Case Study of Marakwet West Sub County, Elgeyo Marakwet County, Kenya
}

\author{
William K Kilimo \& Dr. Nambuswa
}

To Link this Article: http://dx.doi.org/10.6007/IJARBSS/v8-i8/4444

DOI: 10.6007/IJARBSS/v8-i8/4444

Received: 09 July 2018, Revised: 19 July 2018, Accepted: 29 July 2018

Published Online: 22 August 2018

In-Text Citation: (Kilimo \& Nambuswa, 2018)

To Cite this Article: Kilimo, W. K., \& Nambuswa. (2018). Factors Influencing Sustainability of Rural Water Supplies Management in Kenya: A Case Study of Marakwet West Sub County, Elgeyo Marakwet County, Kenya. International Journal of Academic Research in Business and Social Sciences, 8(8), 112-123.

Copyright: (C) 2018 The Author(s)

Published by Human Resource Management Academic Research Society (www.hrmars.com)

This article is published under the Creative Commons Attribution (CC BY 4.0) license. Anyone may reproduce, distribute, translate and create derivative works of this article (for both commercial and non-commercial purposes), subject to full attribution to the original publication and authors. The full terms of this license may be seen at: http://creativecommons.org/licences/by/4.0/legalcode

Vol. 8, No. 8, August 2018, Pg. 112 - 123

Full Terms \& Conditions of access and use can be found at http://hrmars.com/index.php/pages/detail/publication-ethics 


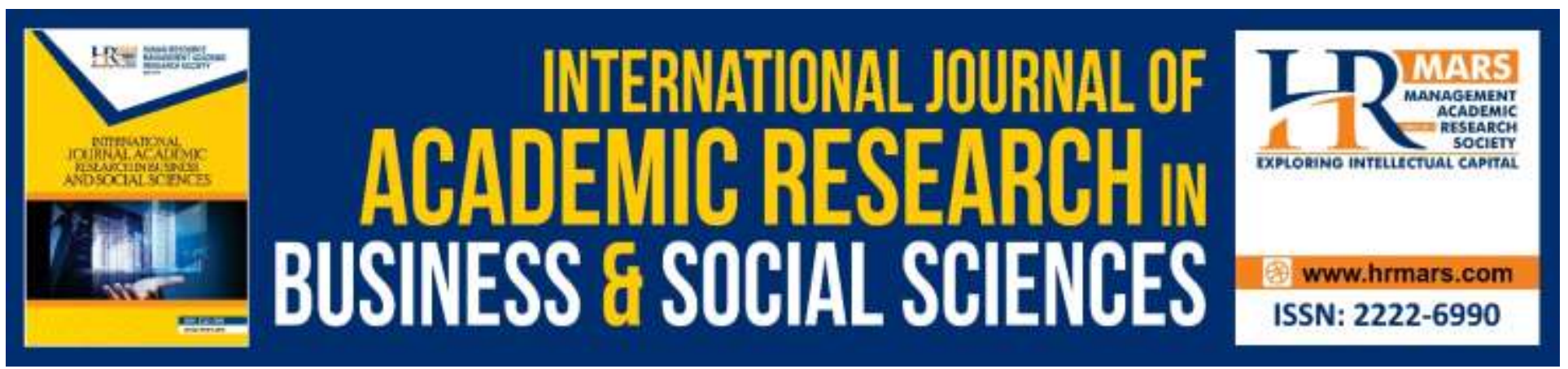

\title{
Factors Influencing Sustainability of Rural Water Supplies Management in Kenya: A Case Study of Marakwet West Sub County, Elgeyo Marakwet County, Kenya
}

\author{
William K Kilimo \& Dr. Nambuswa (Ph.D) \\ Degree of Master of Science in Development Studies of Jomo Kenyatta University of Agriculture and \\ Technology \\ Email: iombaso@gmail.com
}

\begin{abstract}
The purpose of this project was to analyse the Factors influencing Sustainability of Rural Water Supplies Management in Kenya: A Case Study of Marakwet West Sub County Elgeyo Marakwet County Kenya. It was specially want to find out how the level of community participation; socioeconomic status of the community; water financial management and how level of technology penetration in the community influences sustainability of water projects in Marakwet West Sub County. The study adopted a descriptive survey research design. The target population was the community households, programme coordinators and committee members of water projects. A sample of 256 respondents drawn from the target population was used. The study used descriptive and analytical methods of data analysis which were mainly performed using the SPSS data analysis package. The data was analyzed using quantitative analysis method. From the analysis it was found out that majority of the consumers of the water projects were not invited to participate in the project however, they were involved somehow in the project development. It was found out that the committee members were usually selected and not democratically elected to the committee. It was also found that majority of the community members did not receive any training before the projects were handed over to the community. It was recommended that the ministry of water and natural resources and sponsors of water projects should invite many the consumers of the water projects at initiation stage of the projects. Community members should be involved in the projects by being active in contributions either in material or labour. Consumers of water projects in the sub county should be sensitized and be trained on effective and efficiency water usage through forums like barazas or through their respective churches were majority of them can be reached. The frequency training should be shifted from the current-on need basis- to quarterly so that the consumers get privy to the project fully as the trainings slow down. Project handlers to allow consumers of the water projects to carry out democratic elections of their water management committees and those involved in the monitoring and implementation of community water projects. Programme administrators
\end{abstract}


INTERNATIONAL JOURNAL OF ACADEMIC RESEARCH IN BUSINESS AND SOCIAL SCIENCES

Vol. 8, No. 8, August 2018, E-ISSN: 2222-6990 @ 2018 HRMARS

should make efforts of training locals on the relevant technological applied in the water projects before handing over the project so that locals can take charge effectively once the project has been handed over to them.

Keywords: Community Participation, Sustainability, and Water Management.

\section{Introduction}

Globally, water resources management has been acknowledged to be difficult requiring the integration of various types of information in the context of uncertainty, heterogeneity, competing objectives and limited resources (Park, Roberts, Alexander, McNamara, \& Pannell, 2013). In Europe, the Water Framework Directive provides a high-level legal framework within which Member States are responsible for developing river basin-based approaches for meeting 'good ecological status for all waters (Patterson, Smith, \& Bellamy, 2013). Similarly, in Canada, the South Saskatchewan River Basin (SSRB) provides an example of river basin governance situation characterized by decentralized, multilevel with assigned water licenses as asserted by Hurlbert and Diaz (2013). Such an assertion has also been made regarding water catchment management in most Western Countries such as MurrayDarling in Australia, Rhine and Danube water basins in Europe which involve integrated approach to managing rivers (Pegram, Yuanyuan, Quesne, Speed, Jianqiang, \& Fuxin, 2013). Nearly 10\% of the total burden of disease worldwide is attributable to unsafe water, sanitation, and hygiene and the associated diseases claim 3.6 million lives annually (Pruss-Ustun et al., 2008). For most rural households throughout Sub-Saharan Africa (SSA), there is limited access to safe water resources on the premises, which results in women and children often walking long distances in search of water to fulfill basic daily water requirements (Baker, Cullen, Debevec, \& Abebe, 2015). Water is a basic need for human existence hence a fundamental right (Republic of Kenya, 2010). It plays very important role for the wellbeing of the environment, life forms including various animal species and vegetation (Brauman, 2015). Access to rural water supply remains low in Kenya. In particular, access to piped water has only increased from 9 to 10 percent of rural households over the past eight years. Small community-based water providers are seen as part of the solution and are supported by the Water Sector Act of 2002, which introduced regulatory and tariff reforms. However these small water projects lack funding, especially to improve existing systems (Gok, 2009). According to Mbata (2006) the sustainability of any community projects requires a team of highly competent managers owing to many dynamics of the project implementation. The failure of community based project is largely blamed on lack of professionalism and management skills of the project implementers owing to poor academic background. In order to establish good rapport leaders need time, resources and authority to invest in a project. Flexibility is critical in the way leaders interpret their own and others' roles and in the activities they and the projects undertake (Carter et al. 1999). Therefore, in order to attain sustainable development, improving water resources management has been considered integral to realizing socio-economic development as well as providing environmental services that are sustainable (Kalbus, et al., 2012). This is the motivation for this study, to look at the factors influencing water projects sustainability in Marakwet West Sub County.

\section{Statement of the Problem}

Gebrehiwot (2006) asserts that there is evidence that in developing countries, national and regional governments, local and international NGOs and other concerned organizations invest large sums every year for the implementation of rural water supply projects. In National Water Policy (2002) stipulates that communities are responsible for full cost recovery, which means the recovery of the 
complete cost of the installation of the system, as well as covering costs for operation and maintenance. Therefore sustainability is not just reaching the design life of a technology, but about the ongoing availability of clean, affordable and accessible water. However, construction of water projects is not the panacea to provision of clean water for local communities. This is so because according to the local water board of Elgeyo Markwet West, the projects run down barely into a year after being handed over to the community. This becomes a threat to the many gains like, improving health, reducing the burden of carrying water long distances, and enabling users to live a life of dignity among others that can be accrued if there were sustainable water projects in the sub county. For instance, In order to make the investment in water supplies more effective, failure rates of these systems should be reduced. This was the motivation on the researcher to find out the factors that may influence the Sustainability of Rural Water Supplies Management in Kenya: A Case Study of Marakwet West Sub County Elgeyo Marakwet County Kenya.

\section{Research Questions}

1. How does the level of community participation affect sustainability of water projects in Marakwet West Sub County?

2. How does training affect sustainability of water projects in Marakwet West Sub County?

3. How does project management committee influences sustainability of water projects in Marakwet West Sub County?

4. How the level of technology penetration in the community does influences sustainability of water projects in Marakwet West Sub County?

\section{Research Objectives}

1. To determine the effect of community participation on sustainability of water projects in Marakwet West Sub County

2. To establish the effect of training on sustainability of water projects in Marakwet West Sub County

3. To assess the effect of project management committee on sustainability of water projects in Marakwet West Sub County

4. To determine the effect of technology penetration on sustainability of water projects in Marakwet West Sub County

\section{Literature Review}

\section{Community participation on Sustainability of Community Water Projects}

According to Aras and Crowther (2008), there are four aspects of sustainability, which are needed to be recognized and analyzed, namely; societal influence, which measures the impact a society makes upon the corporation in terms of the social contract and stakeholder influence; environmental impact, which is the effect of the actions of the corporation upon its geophysics environment; organizational culture, which is the relationship between the corporation and its internal stakeholders and finances an adequate return for the level of risk undertaken in pursuit of sustainable development and financial sustainability. Armitage (2003) indicated that citizen participation as a process by which citizens act in response to public concerns, voice their opinions about decisions that affect them, and take responsibility for changes to their community, their support, he pointed out is key for the sustainability of a community project. Pran Manga and Wendy Muckle (Chappel, 2005) 
INTERNATIONAL JOURNAL OF ACADEMIC RESEARCH IN BUSINESS AND SOCIAL SCIENCES

Vol. 8, No. 8, August 2018, E-ISSN: 2222-6990 @ 2018 HRMARS

suggest that stakeholders support may also be a response to the traditional sense of powerlessness felt by the general public when it comes to influencing government decisions.

Admassu et.al., (2002) notes that involvement of the communities is crucial for the sustainability of rural water supply systems. Sustainability rate of rural water supply systems increases as a result of communities' owning and managing their schemes, existence of management organization at the village level, protection of the water point, communities cost recovery for operation and maintenance, technology type and availability of their spare parts and recognition of women. Chappel (2005) indicated that community support increasing project efficiency: therefore, he recommended that there should be consultation with the community during project planning or beneficiary involvement in the management of project implementation or operation to ensure project sustainability.

\section{Project Management Committee on Sustainability of Community water Projects}

Human capacity development through specialized training of project managers, staff, community members and the whole project team has been noted to be important for project success and sustainability. (Campo, 2008), in an intervention model introduced in Peru for water supply considered community training as an important component in which the project used various methods of training such as audio-visuals, visual etc., argues that training on issues like operation and maintenance empower the communities to look after water supply systems thus aiding sustainability. Lack of community training is cited as one of the factors which could lead to breakdown and nonsustainability of water supply projects in developing countries (Ademiluyi and Odugbesan, 2008). They further point out that even where full community participation or management is planned from the start, community-level committees and care takers may lose interest or trained individuals may move away. This can be a particular risk if community level organization is on a voluntary basis. (Mengesha, Abera and Mesganaw, 2003) in their study on sustainability of drinking water supply projects in Rural of North Gondar, Ethiopia recommend that building adequate skills and capacity to maintain water sources is an essential factor to sustain the water system. Proasne, (2005). Argues that for water projects to give sustainable results, Project Managers should ensure that there will be funding to support identified solutions to the problems in long term, and for this to happen it is necessary that the technologies used be cost effective and CMs receive instructions on the new techniques as well as training on how to maintain and repair the equipment. Cost effective technologies will give CMs a humble time in terms of repair and maintenance, and this will enhance sustainability of the project.

\section{Management Skills on Sustainability of Community water Projects}

Management of projects involves increasing the alignment of development projects with host communities priorities and coordinating aid efforts at all levels (local, national, and international) to increase ownership and efficient delivery of services. It is therefore basically offering leadership to achieve certain laid objectives. According to McDade (2004), good management ensures that sufficient local resources and capacity exist to continue the project in the absence of outside resources. Community based projects are complex (Weinberg, 2008) and require multifaceted management skills. A project manager (PM) has to manifest not only project management related skills (Kirsch, 2000), but also technical and expertise as required by the project (Thite, 2001). Project management activities include but are not limited to defining project scope and requirements 
gathering, managing resources and relevant training issues within a project, advising about technical architecture, identifying specific and general project management practices and escalation procedures, estimating project schedule and budget, ascertaining and managing risks within a project and preparing risk mitigation. The matching or fit between a PM and project extends not only to the technical skills as enumerated above, but also to other general project-PM profile attributes, such as prior exposure to the methodology experience (Swanson and Beath, 2000). A PM is likely the most senior person within a project and is often perceived as a sounding board for technical and architectural decisions made for the project. In addition, the PM is also expected to demonstrate a deep knowledge of the business objectives of the project being undertaken (Bloom, 2006). Prior literature has shown that task familiarity helps in improving performance and increasing sustainability of a project (Goodman and Leyden, 2001). Prior exposure to the project characteristics such as technology, or methodology would make the current task more familiar to the PM, and hence improve sustainability (Banker and Slaughter, 2000). According to Espinosa, et al. (2007) task familiarity is important in the community based projects and this is usually linked to performance which in turn is linked to sustainability. As irsch (2000) and Thite (2001) suggest, a PM should be able to take on the leadership role with respect to not only managing the project but also leading the technological initiatives. McDade (2004) indicated that individuals with good management skill are considered to be good leaders and therefore, through their leadership organizations are steered to prosperity. Precise nature of leadership and its relationship to key criterion variables such as subordinate satisfaction, commitment, and performance is still uncertain, leadership does remain pretty much of a 'black box' or unexplainable concept. Kirsch (2000) has highlighted that successful project management requires both hard and soft skills. Hard skills comprise technological skills, domain expertise, experience as well as project management experience, and project management skills such as planning, monitoring, risk management and scheduling. Soft skills are intangible, and are primarily concerned with managing and working with people and fostering inter- and intraorganizational 'relationships.'

\section{Technology on Sustainability of Community Based Projects}

Project manager have always appreciated the role technology plays in the production process, project performance, and human welfare (Sampat, 2006). Repeated economic crises and steadily increasing failure in community projects, brought about in particular by poor management and accountability, are forcing an unprecedented rationalization of resources (Hagedoorn and Cloodt, 2003). Sustainability has thus become a concern of all community projects. At the same time, technology is developing with blinding speed and is becoming the principal instrument for meeting this concern. This explains why many community based projects are investing large amounts of money in implementing information systems. However, the advantages offered by technologies, especially in terms of enhancing productivity, depend upon how well these technologies are integrated into the projects objectives.

Recently, Information Technology (IT) has moved beyond the implementation of IT applications to an age of IT-enabled change. The trend towards increasing use of IT continues and the challenge remains how to better manage IT projects in order to maximize their economic benefits. Mbithi and Rasmuson, (1999) stressing the importance of technology on sustainability of community based projects indicated that, sustainability of rural water supply system depends on factors controlled by the project like; training, technology, cost of the project and construction quality and factors that are not controlled by the project for example, communities' poverty level, access to technical assistances 
INTERNATIONAL JOURNAL OF ACADEMIC RESEARCH IN BUSINESS AND SOCIAL SCIENCES Vol. 8, No. 8, August 2018, E-ISSN: 2222-6990 @ 2018 HRMARS

and spare parts. Adoption of technology is important in sustainability of community based water projects as it eases operations and maintenance. The effective operation and maintenance (O \& M) of rural water supply systems is crucial element for the sustainability of the water project. The community management of rural water supply systems on operation and maintenance $(O \& M)$ is not successful, if financing resources are not available and frequent supports are not provided (Binder, 2008). Budgeting sufficient funding for rural water supply systems is an important issue for sustainability and proper maintenance but not only one. Technological innovation has enormous influence on community based project (Nohria and Gulati, 2006). Technological innovation should also be an important factor influencing the improvement of performance and therefore ensuring project sustainability. With more rapid technical change, it has become clear that the ability of organizations to develop innovative new products and services is a crucial influence on sustainability (Hitt \& Rothaermel, 2003). Numerous studies have repeatedly shown a positive relationship between a project's technological innovation and project sustainability, and concluded that technological innovation is important for performance and sustainability (Foster, 1986).

\section{Conceptual Framework}

The conceptual framework from figure 1.1 shows the relationships between and among variables as they interacted in the study.

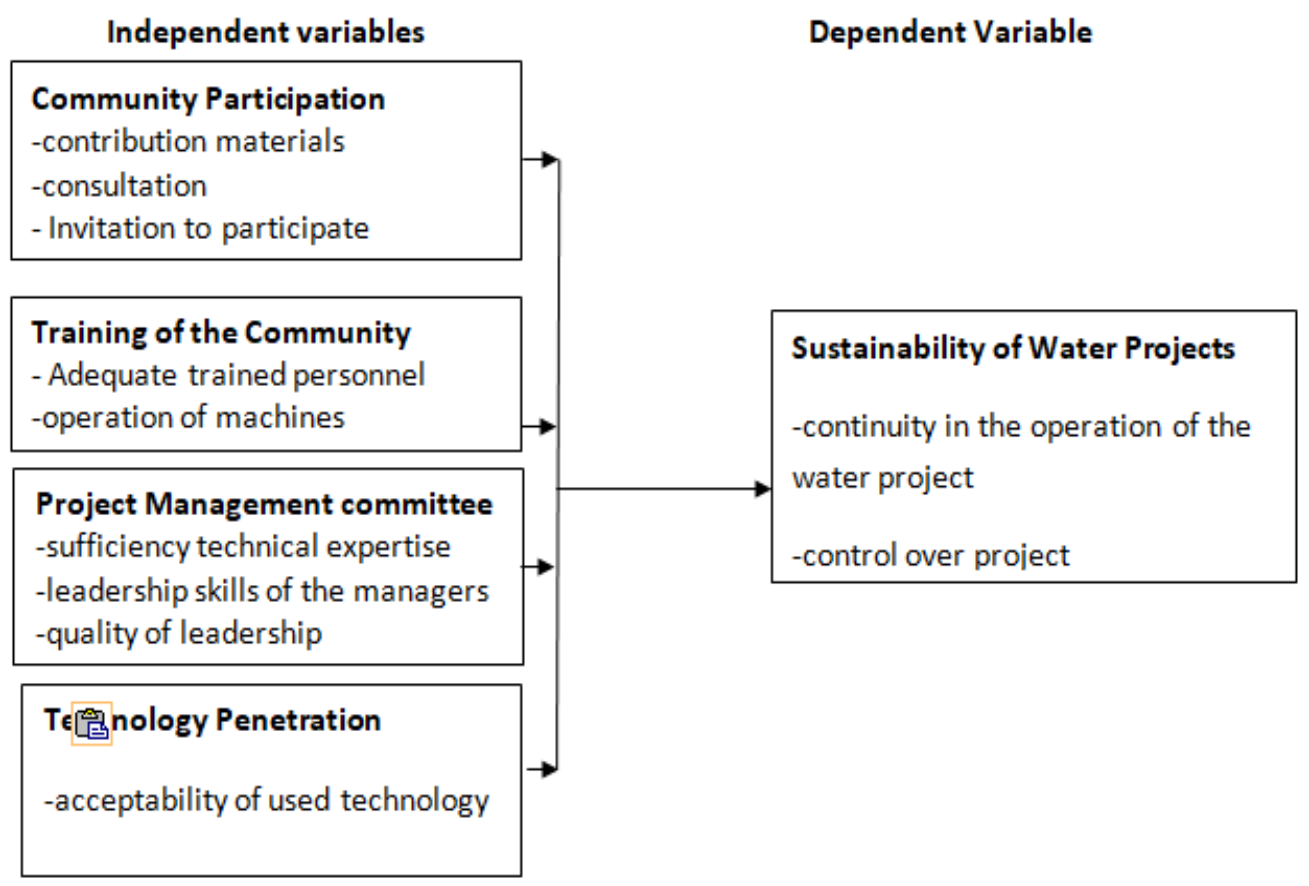

\section{Methodology of Research Research Design}

The study adopted a descriptive design. This type of design is quite appropriate for gathering information, summarizing, presenting and interpreting for the purpose of clarification (Orodho, 2002). The descriptive survey design is one of the most commonly used methods of descriptive research in behavioral science. It enables the researcher to gather qualitative and quantitative data 
INTERNATIONAL JOURNAL OF ACADEMIC RESEARCH IN BUSINESS AND SOCIAL SCIENCES

Vol. 8, No. 8, August 2018, E-ISSN: 2222-6990 @ 2018 HRMARS

from a relatively large number of cases at a particular time. The method is quite appropriate for the study because it will assist the researcher to produce statistical information on factors influencing sustainability.

\section{Data Collection, Instruments and Sampling Techniques}

The researcher will obtain an introduction letter from JKUAT, and obtain a research permit from the National Council for Science and Technology and innovations. Thereafter, the researcher will obtain consent from the Sub County water office to administer the to their project questionnaires. The researcher visited each of the sampled departments and households to personally administer the questionnaires. The respondents were guided on how to respond to the questions and were assured of confidentiality of all the information they gave. After which they were given the questionnaires to fill within seven days and return them to the researcher through an agreed collection point. Questionnaires will be used as the data collection instrument. (Glasser and Strauss, 2007) explains that questionnaires are an important instrument for research; a tool for data collection. The use of questionnaires is justified because they are an effective way of collecting information from a large sample in a short span of time and at a reduced cost than other methods. Further, questionnaires will facilitate easier coding and analysis of data collected. The researcher will administer the questionnaires both in person and through the help of field assistants by visiting the respondents. To obtain the sample for households where the population is infinite, a sample of 196 people was determined using the formulae below. Where the population is infinite $N=(Z / d)^{2} P(1-P)$, $\mathrm{P}$ - estimated value for the proportion of a sample that will respond in a given way to a survey (.5 for $50 \%)$. Simple random sampling will be used to determine the sample for ward officers and since there are 6 wards to be studied, 6 ward officers are to make the sample. 30\% of the committee members will be used as sample for the sample hence, 57 committee members.

\section{Data Analysis}

Before the data was analyzed all questionnaires were first checked to find out whether they are answered adequately. The information was then coded and entered into a spreadsheet and analyzed using SPSS (Statistical Package for Social Sciences). The study used descriptive and analytical methods of data analysis which were mainly performed using the SPSS data analysis package. The data was analyzed using quantitative analysis method. The data was presented by use of tables, bar charts and pie charts for ease of reference.

\section{Results of the Study Hypothesis One}

Ho1: There is no significant relationship between the level of community participation and sustainability of water projects in Marakwet West Sub County.

From the findings, community participation $(\beta=0.622)$ was found to be positively related sustainability of water projects. From t-test analysis, the $t$-value was found to be 4.985 and the $\rho$ value 0.000 . Statistically, this null hypothesis was rejected because $\rho<0.05$. Thus, the study accepted the alternative hypothesis and it concluded that community participation affects sustainability of water projects in Marakwet West Sub County. 
INTERNATIONAL JOURNAL OF ACADEMIC RESEARCH IN BUSINESS AND SOCIAL SCIENCES

Vol. 8, No. 8, August 2018, E-ISSN: 2222-6990 C 2018 HRMARS

\section{Hypothesis Two}

Ho2: There is no significant relationship between training and sustainability of water projects in Marakwet West Sub County.

From the findings, training $(\beta=0.354)$ was found to be positively related sustainability of water projects. From t-test analysis, the $\mathrm{t}$-value was found to be 3.387 and the $\rho$-value 0.019 . Statistically, this null hypothesis was rejected because $\rho<0.05$ Thus, the study accepted the alternative hypothesis and it concluded that training affects sustainability of water projects in Marakwet West Sub County.

\section{Hypothesis Three}

Ho3: There is no significant relationship between Proposal management committee and sustainability of water projects in Marakwet West Sub County.

From the findings, proposal management committee $(\beta=0.378)$ was found to be positively related sustainability of water projects. From t-test analysis, the $t$-value was found to be 3.308 and the $\rho$ value 0.024 . Statistically, this null hypothesis was rejected because $\rho<0.05$. Thus, the study accepted the alternative hypothesis and it concluded that Proposal management committee and sustainability of water projects in Marakwet West Sub County.

\section{Hypothesis Four}

Ho4: There is no significant relationship between the level of technology penetration in the community and sustainability of water projects in Marakwet West Sub County.

From the findings, technology penetration $(\beta=3.025)$ was found to be positively related sustainability of water projects. From t-test analysis, the $t$-value was found to be 6.720 and the $\rho$-value 0.000 . Statistically, this null hypothesis was rejected because $\rho<0.05$. Thus, the study accepted the alternative hypothesis and it concluded that technology penetration affects sustainability of water projects in Marakwet West Sub County.

\section{Recommendations}

Based on the findings, the researcher recommended the following:

i. Communities should be invited and given a chance to participate as leaders in the committee when preparing proposals to enhance sustainability of water projects.

ii. Communities involved in water services should be empowered to have technical and expertise as to operate the equipment or on maintenance of the equipment.

iii. There are adequate competent personnel to manage the proposal for prosperity.

iv. Management of proposals in Water Company should increase the alignment of development proposals with host communities' priorities.

v. They should adopt and embrace modern technology in sustainability of community based water projects for ease of operations and maintenance and for proper management and accountability.

\section{Areas for Further Research}

This study dwelled on analyzing factors influencing sustainability of rural water supplies management in Kenya: a case study of Marakwet west sub county Elgeyo Marakwet county Kenya. The following are suggestions for further research study: A study should be done to investigate Determinants of water loss in the water companies in private entities. 
INTERNATIONAL JOURNAL OF ACADEMIC RESEARCH IN BUSINESS AND SOCIAL SCIENCES

Vol. 8, No. 8, August 2018, E-ISSN: 2222-6990 @ 2018 HRMARS

\section{References}

Abu-Eid, A. (2007) 'Water as a Human Right: Palestinian Occupied Territories.' International Journal of Water Resources Development, 36.

Ademiluyi, I. A., and Odugbesan, J. A. (2008). African Journal of Agricultural Research Vol. 3 (12), pp. 811-817, December, 2008.

Admassu, M., Kumie, A., \& Fantahun, M. (2002). Sustainability of Drinking Water Supply Projects in Rural of North Gondar, Ethiopia, Ethiopian Journal of Health Development, 2003(3):221-229.

Agwata, J. F., \& Abwao, P. (2007). A Review of Multilateral Agreements and their Implications for Environmental Governance in Kenya. In Waswa, F., Otor, S., Olukoye, G., \& Mugendi, D. (eds), Environment and Sustainable Development: A Guide for Higher Education in Kenya, Volume 2. School of Environmental Studies and Human Sciences, Kenyatta University. 209223

Amit, R., \& Schoemaker, P J H. (1993). Strategic assets and organizational rent, Strategic Management Journal, 14 (1), 33-46.

Baker, T., Cullen, B., Debevec, L., \& Abebe, Y. (2015). A socio-hydrological approach for incorporating gender into biophysical model and implications for water resources research. Applied Geography, 62, 325-338.

Baker, R. D., \& Slaughter, S. A. (2000). The moderating effects of structure on volatility and complexity in software enhancement. Information Systems Research 11(3) 219-240.

Brauman, K. (2015). Hydrological ecosystem services: Linking ecohydrologic processes to human wellbeing in water research and watershed management. WIREs Water.

Campos, M. (2008). Making sustainable water and sanitation in the Peruvian Andes: An Intervention Model. Journal of Water and Health 6 (1) 2008.

Carter, R., Tyrrel, S., and Howsam, P. (1999). The impact of sustainability of community water supply and sanitation programs in developing countries. Journal of Chartered Institute of Water and Environment Management. 13, 292.

Cech, T. V. (2010). Principles of Water Resources History, Development, Management, and Policy. John Wiley \& Sons, Inc., River Street, Hoboken, USA.

Espinosa Nohria, N., \& Gulati, R. (2007). Is slack good or bad for innovation? Academy of Management Journal, 39, 245-64.

Gebrehiwot, M. (2006). An Assessment of Challenges of Sustainable Rural Water Supply: The Case of Ofla Woreda in Tigray Region. Msc Thesis, Regional and Local Development Study (RLDS). A.A.U. Ethiopia.

Gizachew, G. (2005) Innovation: The Attacker's Advantage, Summit Books, New York, NY.Goodman and Leyden, (2001). Community development: A critical approach. Bristol, UK: Policy Press.

Hurlbert, M., \& Diaz, H. (2013). Water governance in Chile and Canada: A comparison of adaptive characteristics. Ecology and Society, $18(4), 61-75$.

Hagedoorn, J., \& Cloodt, M. (2003). Measuring innovative performance: Is there an advantage in using multiple indicators, Research Policy, 32(8), 1365-1379.

Harvey, P., \& Reed R. (2004). Rural Water Supply in Africa: Building Blocks for Sustainability: Loughborough University UK: Water, Engineering, and Development Centre (WEDC).

Hill, C. W. L., \& Rothaermel, F. T. (2003). The performance of incumbent firms in the face of radical technological innovation, Academy of Management Review, 28(2), 257-74.

International Water Management Institute. (2007). Water for food Water for life: A Comprehensive Assessment of Water Management in Agriculture. London, Earthscan, and Colombo. 
INTERNATIONAL JOURNAL OF ACADEMIC RESEARCH IN BUSINESS AND SOCIAL SCIENCES Vol. 8, No. 8, August 2018, E-ISSN: 2222-6990 @ 2018 HRMARS

Jiang, Y. (2009). China's water scarcity. Journal of Environmental Management, 90, 3185-3196.

Kalbus, E., Kalbacher, T., Kolditz, O., Kruger, E., Seegert, J., Rostel, G., et al. (2012). Integrated water resources management under different hydrological, climatic and socio-economic conditions. Environment Earth Science, 65, 1363-1366.

Len, A. (2003). Understanding Sustainability of Local Water Services; Water Policy International, South Africa.

Mbata, J. (2006) Estimating Household Willingness for Water Services in Rural economy: The Case of Kanye in Southern Botswana. Development of Southern Africa, 23(1), 29 - 43.

McDade S. (2004) December. Gender and Energy for Sustainable Development: A Toolkit and Resource Guide. New York, NY. United Nations Development Programme.

Mihelcic, J. R., Crittenden J. C., Small, M. J., Shonnard, D. R., Hokanson, D. R., Zhang, Q., Chen, H., Sorby, S. A., James, V. U., Sutherland, J. W., \& Schnoor, J. L. (2003). Sustainability science and engineering: emergence of a new metadiscipline. Environmental Science \& Technology, 37 (23), 5314-5324.

Park, G., Roberts, A., Alexander, J., McNamara, L., \& Pannell, D. (2013). The quality of resource condition targets in regional natural resource management in Australia. Australasian Journal of Environmental Management , 20 (4), 285-301.

Patterson, J., Smith, C., \& Bellamy, J. (2013). Understanding enabling capacities for managing the 'wicked problem' of nonpoint source water pollution in catchments: A conceptual framework. Journal of Environmental Management, 128, 441-452.

Pegram, G., Yuanyuan, L., Quesne, T., Speed, R., Jianqiang, L., \& Fuxin, S. (2013). River basin planning: Principles, procedures and approaches for strategic basin planning. Paris : UNESCO.

Pruss-Ustun, A., Bos, R., Gore, F., and Bartram, J. (2008). Safer Water, Better Health: Cost, Benefits and Sustainability of Interventions to Protect and Promote Health. Geneva: World Health Organization.

Republic of Kenya. (2010). Laws of Kenya: The constitution of Kenya. Nairobi: National Council for Law Reporting.

Republic of Kenya. (2009). Kenya Demographic Household Survey. National Bureau of Statistics, Government Printer, Nairobi, Kenya.

REMPAI. (2009). Kenya Natural Resources Management Project: A Baseline Survey. REMPAI, Nairobi. Republic of Kenya. (2007a). Kenya Vision 2030. A Globally Competitive and Prosperous Kenya. Ministry of Planning and National Development: Government Printer, Nairobi, Kenya.

Republic of Kenya. (2009). Kenya Demographic Household Survey. National Bureau of Statistics, Government Printer, Nairobi, Kenya.

Republic of Kenya. (2010). The Constitution of Kenya: Government Printer, Nairobi, Kenya.

UN. (2000). Agenda 21: Earth Summit-The United Nations Programme of Action from Rio. Rio de Janeiro, Brazil: United Nations Division for Sustainable Development

UNEP. (2004). Integrated Urban Water Resources Management Strategy, Water, UNEP, Nairobi, Kenya.

UNESCO. (2003). World Water Assessment Programme. Water for People; Water for Life: The United Nations World Water Development Report. Oxford, New York.

UNDP-WSP. (2006). Getting Africa on Track to Meet MDGs on Water and Sanitation: A Status Overview of Sixteen African Countries. Nairobi, Kenya: Water and Sanitation Program-Africa, World Bank. 
INTERNATIONAL JOURNAL OF ACADEMIC RESEARCH IN BUSINESS AND SOCIAL SCIENCES

Vol. 8, No. 8, August 2018, E-ISSN: 2222-6990 @ 2018 HRMARS

UNICEF \& WHO. (2004). Meeting the MDG Drinking Water and Sanitation Target Mid-Term Assessment of Progress. UNICEF, Division of Communication, United Nations Plaza, New York, USA.

WHO/UNICEF, (2008). Progress on Drinking Water and Sanitation: Special Focus on Sanitation. New York: UNICEF, Geneva: WHO. 